\title{
ITÄINEN JA LÄNTINEN LUKUTAITO
}

\begin{abstract}
"Läntisen, teollistuneen maailman vallankäyttäjä tarvitsisi kipeästi sitä neljättä lukutaitoa, joka muodostuu siitä elämän eheydestä ja kokonaisuuden ymmärtämisestä, jota eri kulttuureissa edustavat tavat, riitit ja myytit sekä tästä ykseydestä syntyneet ikimuistoiset sosiaaliset käytännöt", kirjoittaa Vantaan kirjastotoimenjohtaja Hannele Koivunen. Hän näkee länsimaisessa ihmisessä avuttomuutta, kun pitäisi osata lukea eleitä, ilmeitä tai luontoa.
\end{abstract}

Entä asian toinen puoli? Olemmeko oman elämänmallimme viennillä vaarantamassa tämän "neljännen lukutaidon" niissä kulttuureissa, jossa se hallitaan? Onko niin - kuten kirjoittaja toista artikkelia lainaten toteaa -, että lukutaidon leviäminen on perustavampaa ja kohtalokkaampaa kulttuuri-imperialismia kuin mitkään taivaskanavat?

Opintomatkallani Kiinassa oppaanamme Chengdessä toimi topakka pyöreäposkinen noin kaksikymmenvuotias tyttö. Kerroin hänelle halunneeni aina matkustaa Kiinaan nähdäkseni oikein elävän lohikäärmeen. Opas katseli minua hetken vakavana arvioiden ja sanoi sitten hyvin varmana: "Dragons are quite imaginery animals".

Esimerkki kuvaa hyvin globaalia proses. sia, jossa itäinen ja läntinen ihminen tuntevat tarvetta täydentää olemuksensa vajaata puolta. Siinä missä läntinen ihminen kaipaa itäistä mytologiaa, symboliikkaa ja mystiikkaa löytääkseen itseymmärryksen, itäinen ihminen tarrautuu läntiseen rationalismiin. Oikean ja vasemman aivolohkon vuorovaikutuksessa ihmiskunta etsii ja täydentää kollektiivista tajuntaansa.

\section{Uuteen aika- ja käsiteavaruuteen}

Kirjoitusmerkit ja lukutaito irroittivat ihmisen nykyhetkestä. Hänelle tuli mahdolliseksi peilata ajatuksiaan, menneisyyttä ja tulevaisuutta. Hän saattoi myös irrota omasta kulttuuristaan. Myöhemmin hän oppi jopa irroittamaan tunteensa omasta ja siirtämään sisimpänsä kirjoitukseen. Tätä kautta hän saattoi etääntyä itsestään. Vuorovaikutus toisen kanssa ei enää edellyttänyt samanaikaista läsnäoloa. Käsitteellisestä viestistä jäi pois silmän, nenän ja korvan välittämä totuus viestin lähettäjästä.

Kirjoitus- ja lukutaidon merkitystä ihmisen vieraantumisprosessissa tai oikean ja vasem. 
man aivolohkon funktionaalisessa eriytymisessä ei liene paljon tutkittu. Se merkitsi kuitenkin valtavaa tajunnallista laajentumista aika- ja käsiteavaruudessa. On selvää, ettei meidän yhä monimutkaistuvassa kulttuurissamme ole enää mahdollista tulla täysipainoisesti toimeen ilman lukutaitoa. Teknisen ja rationaalisen läntisen maailman vallan. käyttö perustuu lukutaitoon, samoin itäisissä kulttuureissa lukutaito vanhastaan edusti sa. laisuuksien hallintaa.

Kirjoitettu sana alkaa hallita ihmisiä. Lukutaitoa opetetaan ylhäältä annettuna velvoituksena. Suomalaiseen yhteiskuntaan sitä juurrutettiin Seitsemän veljeksen esimerkin mukaisesti mekaanisena taitona, jota tarvittiin kirkon vallan vahvistamiseksi, lähinnä Katekistuksen iskostamiseksi kansan tajun. taan.

Lukutaitoa ei mielellään opetettu vallankäytön kohteille, orjille ja työläisille, ennen kuin yhteiskunnallinen kehitys edellytti sitä työstä suoriutumisen ehtona.

\section{Kansainvälisiä tietoja lukutaidottomuudesta}

Vuonna 1985 maailmassa oli yli viisitoista vuotta täyttäneitä ja sitä vanhempia 3,2 mil. jardia. Heistä 889 miljoonaa eli yksi neljästä aikuisesta, 27,7 prosenttia oli lukutaidottomia Unescon määritelmän mukaan. "He eivät kyenneet lukemaan eivätkä kirjoittamaan yksinkertaista kertomusta jokapäiväisestä elämästään." (Unescon suorittama lukutaidottomuuden määritelmä vuodelta 1978, Revised Recommendation concerning the International Standardization of Educational Statistics).

Suurin osa lukutaidottomista löytyy kehitysmaista, teollisuusmaissa heitä on vain 2,1 prosenttia tai 20 miljoonaa. Maanosittain tarkasteltuna lukutaidottomia on eniten Aasias. sa. Heitä on siellä 666 miljoonaa eli 75 prosenttia maailman lukutaidottomien kokonaismäärästä. Seuraavana tulee Afrikka, missä on 162 miljoonaa lukutaidotonta eli 18 prosenttia lukutaidottomien kokonais. määrästä ja sitten seuraavana Latinalainen Amerikka ja Karibia 44 miljoonalla ja 5 pro. sentilla kokonaismäärästä.

Maailman lukutaidottomien suhteellinen prosentuaalinen määrä on vähenemässä, mutta väestönkasvun ja maailman talouskrii- sin valossa luvut osoittavat absoluuttista määrien kasvua. Tällä hetkellä yli viisitoista. vuotiaista lukutaidottomia lienee jo yli miljar. di. (Lähde YK-tiedote 4/98).

Lukutaidottomuus ei kuitenkaan ole yksin kehitysmaiden ongelma. Teollisuusmaissa uuslukutaidottomuus lisääntyy koko ajan. Esimerkiksi Yhdysvalloissa lukutaidottomak. si määritellään henkilö, joka on ohittanut pakollisen oppivelvollisuusiän (16-vuotias tai vanhempi), mutta jonka koulutuspohja on riittämätön tehokkaaseen toimintaan yhteis. kunnassa. Näitä toiminnallisesti, funktionaa. lisesti lukutaidottomia arvioidaan Yhdysval. loissa olevan 30.50 miljoonaa.

Aikuiskasvatus-lehden numerossa 1/89 on Carrol A. Londonerin artikkeli, jossa kerrotaan Amerikan aikuis- ja jatkuvan kasvatuksen yhdistyksen (The American Association for Adult Continuing Education, AAACE) lukutaito-ohjelmasta.

Perinteinen lukutaito, jonka kriteerein maailman lukutaidottomuustilastot on tehty, on kuitenkin vain perusta. Kuten yhdysvaltalainen tilastointiesimerkki osoittaa, lukutaito voidaan määritellä syvemmin toimintakykynä. Tämän funktionaalisen lukutaidon lisäksi on alettu puhua myös ns. toisesta lukutaidosta ("second literacy").

Tietokoneyhteiskunnassa elävän ihmisen katsotaan tarvitsevan lukutaidon kolme ulottuvuutta: painetun tekstin kirjoitus- ja lukutaito ("print literacy"), joukkoviestimien lukutaito ("media literacy") ja tietokonelukutaito ("computor literacy"). Näin määritellyin kriteerein Suomenkin lukutaidottomuus alkaisi näyttää toisenlaiselta, vaikka maamme on perinteisesti mielletty lukutaidon kärkimaihin ja vaikka meillä uuslukutaidottomuus ei vielä näyttäydy yhtä laajana ongelmana kuin jo esimerkiksi Ruotsin kehitys osoittaa. Suomessakin kuitenkin noin 10-15 prosenttia aikuisväestöstä on luku- ja kirjoitushäiriöisiä.

\section{Lukutaidottomuus ja naiset}

Lukutaidottomuus, köyhyys, väkivaltaisuus ja vallan puute kulkevat käsi kädessä muodostaen kierteen. Naiset kuuluvat kaikkialla maailmassa tähän joukkoon. Lukutaidottomia naisia on enemmän kuin miehiä ja sukupuolten välinen lukutaidottomuuskuilu kasvaa väestökehityksen myötä. Se on jyrkin vähiten kehittyneissä maissa, sitten Afrikas- 
sa, kehitysmaissa, Latinalaisessa Amerikassa ja Karibiassa.

Erilaisten määritelmien mukainen lukutaito korostaa läntisten teollistuneiden maiden miehisiä, teknisiä selviytymistaitoja. Lukutaidottomuuden avulla sortaminen jatkuu myös nais- ja mieskulttuurien juopaa syventävänä, itäisten ja läntisten kulttuurien perusteiden eroa polarisoivana ja vähemmistöjä tuhoavana vallankäyttönä.

Lukutaidon lisääntyminen maailmassa on lisännyt ekokatastrofia edistävän teknisen kulttuurin lisääntyvää ylivaltaa. Kehitysmaihin on siirretty mekaanisesti tiedon nimissä sinne sopimattomia menettelytapoja lähtemättä paikallisten kulttuurien lähtökohdista. Maailma on täynnä esimerkkejä siitä, miten lukutaidon, tieteen ja tiedon nimissä on tehty valtavia virheitä, jotka olisi voitu välttää kuuntelemalla ja ymmärtämällä lukutaidottomia. Ihmiskunnan kommunikaatio- ja oppimisprosesseissa on kuitenkin tilanne, jossa lukutaito on tämänhetkinen avain myös tällaisen todellisen, hedelmällisen ja ymmärtävän eri kulttuurien vuorovaikutuksen edistämisessä.

On tärkeää oivaltaa, ettei lukutaidon mekaaninen levittäminen ole sinänsä hyvä tai paha ja että sen nimissä voidaan tuhota tai rakentaa; tuhota kulttuurien hienoja, kirjoittamattomia rikkauksia ja tahoja tai edistää niitä ja saattaa ne muiden tietoon.

Eräät tutkimukset ovat osoittaneet, miten esimerkiksi eräiden kriteerien ja tutkimusotteiden mukaisesti lukutaidottomaksi määritellyt naiset osoittautuivat lukutaitoisiksi ja lahjakkaiksi, kun kyselytapaa siirrettiin koskemaan riittävästi heidän elämäntilanteitaan ja käytettiin heidän kommunikointitapaansa.

Läntinen, teollistuneen maailman vallankäyttäjä tarvitsisi kipeästi sitä "neljättä lukutaitoa", joka muodostuu siitä elämän ehey. den ja kokonaisuuden ymmärtämisestä, jota eri kulttuureissa edustavat tavat, riitit ja myytit sekä tästä yhteydestä syntyneet ikimuistoiset sosiaaliset käytännöt. Läntinen harhainen lineaarinen aikakäsitys ja esimerkiksi psyykkisten ongelmien ratkominen analysoimalla ja pirstomalla eheyttä palasiksi ovat eräitä esimerkkejä liian mekaanisista malleista verrattuna sykliseen aikaan ja ihmisen ja maailman ykseyteen ja keskinäistä vuorovaikutusta korostavaan ja sitä kautta terveyttä edistävään elämäntapaan. Teollistuneen maailman lukutaidon käyttäjä voi olla täysin avuton, kun pitäisi osata lukea eleitä, ilmeitä tai luontoa.
Tämä vallankäyttö ja karkeistaminen näkyvät meidän kulttuurissamme sisälläkin asennoitumisena vähemmistöjä ja vähäväkisiä kohtaan. Siitä ei ole kovin kauan, kun vihainen asiakas soitti minulle arvostellakseen Vantaalla Koivukylän kirjastossa tänä keväänä järjestettyä yökirjastokokeilua, jossa kirjastoa on pidetty perjantai-iltaisin avoinna kello kahteen saakka yöllä, jotta kaduilla oleskelevilla "ongelmanuorilla" on ollut joku paikka, minne tulla. Vihaisen asiakkaan painavia argumentteja oli muun muassa se, ettei niitä nuoria saa laskea sisälle kirjastoon, vaan heidät pitäisi heittää sieltä pois myös päivisin, koska "ne tuskin osaavat edes lukea".

Kyösti Rantasalo kirjoittaa Parnassossa 7/87 artikkelissa Lukutaidottomuuden ihme koululainen Henry Aaltosesta Helsingin Malmin alakansakoulussa, jossa hänet heti kättelyssä todettiin tyhmäksi ja lahjattomaksi.

"Vaatimaton asema lahjakkuuden normaalikäyrällä ei mitenkään heilautta. nut tyhmän pikkujätkän itsetuntoa. Hänellä oli vaistomainen kyky kääntää ikä. vätkin olosuhteet voitokseen: 'Mua kiin. nostaa kaikki asiat koulussa enemmän kuin itse koulu. Mä kehitin semmosia juttuja että mä en halunnu jäädä millään vek sieltä vaan halusin mennä sinne joka aamu; semmosia määrättyjä pikkujätkien koukeroita, että mikä on nastaa, kenen kanssa on kiva leikkiä.

Vanhanmallisessa kansakoulussa, jossa Henry Aaltonen opintiestä kulki, oli varmaan parasta sen tehottomuus. Oppilasmääriltään isoissa luokissa saattoi puuhata omiaan ja kehittää taitojaan juuri sillä hetkellä kiinnostavissa lajeissa antamatta opetuksen kohtuuttomasti häiritä. Henry komennettiin luokasta käytävään siksi aikaa kun lahjakkaat opiskelivat. Nykypäivän peruskoulussa hänet olisi lähetetty psykologin käsitte. lyyn. Ja siitä selviät vasta sitten, kun olet tunnustanut, että sinulla on Ongel. ma."

Henrystä tuli nuorisoidoli Remu Aaltonen ja sen jälkeen hänet kutsuttiin äidinkielen opettajien seminaariin, missä hän oli yhtä toivoton lehtoreille kuin ennenkin, koska hän ei pysty selittämään, mikä on hänen laulu. jensa "sanoma" tai mikä on elämän "tarkoitus". 


\section{Läntisen ihmisen \\ "neljäs lukutaito"}

Kuluva lukutaitovuosi on hyvä asia, koska se panee meidät pohtimaan, miten ymmär. rämme ja miten kommunikoimme. Lukutaito on hyvä asia, jos se tarkoittaa oikean ja vasemman aivolohkon, mieheyden ja naiseuden, idän ja länen, yinin ja yangin harmoniaa. Samalla kun kampanjoimme kehitysmaiden peruslukutaidon tai teollistuneiden maiden kolmilukutaidon puolesta, pitäisi kampanjoida teollistuneiden maiden ja kaikkien maiden vallanpitäjien "neljännen lukutaidon" puolesta, näkemisen, kokemisen, koskemisen, haistamisen, kuuntelemisen, mietiskelyn, rauhallisen ja kiireettömän sosiaalisen kohtaamisen ja eheyden ymmärtämisen puolesta. Lukutaidon määrittelyä pitää entisestään laajentaa. Eli Kyösti Rantasalon artikkelin sanoin:
"Meille litteraateille alitteraatit ovat olemassa vain negatiiveina, heidän kirjallisuutensa on 'kirjoittamatonta: On ty. perää ihannoida oppimatonta kansaa, mutta yhtä asiatonta on kytkeä lukutaidottomuus tietämättömyyteen. Ajattelu, ilmiömaailman jäsentäminen ja abstrahointi vain noudattaa eri lakeja silloin, kun tukena ei ole kirjoitettua kieltä. Sen tutkiminen tästä kirjallisesta kulttuurista käsin näyttää vaativan kulttuuriantropologeista hyvin monimutkaista käsiteapparatuuria.

Lukutaidon leviäminen on perustavampaa ja kohtalokkaampaa kulttuuriimperialismia kuin mitkään taivaskanavat." 